logos_i_ethos_2014_2_(37), s. 7-20

DOI: http://dx.doi.org/10.15633/lie.794

Władysław Zuziak

\title{
Values as a basis for human's education
}

Values exist and have impact; a life without values would be hard to imagine. As Józef Tischner put it, "our world is a world of values." They manifest themselves in the human world and they "need" man. And human beings need values to live, to make decisions and to gain understanding, a feeling of security, and meaning. However, our world is in crisis. We see that a social and cultural reality no longer create a structure in which we feel safe. The tradition in which we were raised and the authorities that are important to us are denied. We often feel that the world has lost its meaning. There comes a time

Władysław Zuziak (Uniwersytet Papieski Jana Pawła II w Krakowie) - rev., prof., lecturer of ethics and philosophy at the Pontifical University of John Paul II in Cracow. Publications - i.a.: Social pespectives of ethics (2006) and Axiology of Louis Lavelle in the face of the postmodern crisis of values (2012). Member of ESSSAT (European Society for the Study of Science and Theology), FUCE (the Federation of European Catholic Universities) and PPS (the Polish Philosophical Society). Fields of research: philosophy of man, ethics, personalism, axiology, $20^{\text {th }}$ century French philosophy.

to consider the world, to reflect on its essence while keeping in mind that "considering the ontology of the world, considering its being, must be joined with consideration of the worlds axiology, of good or values."

Values that emerge in the contemporary world are often strange to us as Christians, they are repulsive or offend our feelings. Frequently we see that while man can discover himself as a result of values, he can also get lost because of values that are harmful to him. Thus, we begin to wonder if there are true values and apparent values, honest and dishonest values humane and inhumane values? In a world which is increasingly 
losing its humane traits, where, as in a in Kafkaesque labyrinth, we feel increasingly lost and dehumanised, we still want to find something dear to us, to share those things which matter and the things we care about with others.

John Paul II was certainly correct when saying that it is necessary to continuously seek "ever more consistent rational arguments in order to justify the requirements and to provide a foundation for the norms of the moral life. This kind of investigation is legitimate and necessary, since the moral order, as established by the natural law, is in principle accessible to human reason. Furthermore, such investigation is well-suited to meeting the demands of dialogue and cooperation with non-Catholics and non-believers, especially in pluralistic societies." ${ }^{3}$ However, we need to consider what common ground we still have with "the rest" of the world. There certainly exist many global values, recognised by most states and compatible with Christian teaching: freedom, equality, fraternity, solidarity, responsibility for the natural environment, pluralism, democracy, and tolerance.

Unfortunately, these values do not contribute to the improvement of the world, and what is even worse, their meaning is changing, which is why, as in the case of freedom, they are turned into their opposites. As Eduard Pickert points out, "in the situation of the increasing aporia of values the only remaining possibility is to resort to the last taboo of a secularised society. Axiological and functional fusion of vital goods with dignity as the highest value becomes a necessity in such circumstances." Human dignity (or, more precisely, the personal value of someone equipped with specific characteristics and dignity ${ }^{5}$ ) is commonly recognised in this world, so it may provide a starting point for discussing the world of values and everything that is important to a human being.

"Research indicates that the educational ideal has an essential dependence on values and human beings. Indeed, the educational ideal should

John Paul II, Veritatis splendor, Rome 1993, no. 74.

E. Pickert, Godność człowieka a życie ludzkie. Rozbrat dwóch fundamentalnych wartości jako wyraz narastającej relatywizacji człowieka, Polish translation by J. Merecki, Warszawa 2007, p. 182.

Cf. R. Spaemann, Osoby. O różnicy między czymś a kimś, Polish translation by J. Merecki, Warszawa 2001, p. 10. 
stem directly from the analysis of the axiological character of human nature and those values that are indispensable for achieving a more perfect human existence and the optimal development of man in all important aspects and on all levels of his structure." 6 Of course, these issues are crucial for us as educators and for our students who we need to provide with the right "tools" for activity and development in this world.

\section{The human being as a value (theoretical ethics)}

The most important value in Christian teaching is the human-person, and the most important moral imperative is to respect the dignity of every human being. What does it mean that the human person is the highest value? It means that he is a goal in and of himself, that his development is the most important factor, and that he cannot be treated as an instrument.

What does it mean to be "a human being?" Every science focused on the human being, and especially "education [...] must from the outset provide an answer to the question: 'who is man?"' ' Without an answer regarding "who" he is, what is his structure, what are his needs or what his essence is, it is difficult for man to find his place and even more difficult to set educational goals.

What can we meaningfully say about the human being? Certainly that "he is more of a process, continuously becoming, and he is never a separate, self-reliant individual being," ${ }^{8}$ but a process - or rather he recognises himself through life and experience. By experiencing, he becomes the subject and the object of cognition, ${ }^{9}$ and he discovers his

6 W. Cichoń, Wartości, człowiek, wychowanie. Zarys problematyki aksjologiczno-wychowawczej, Kraków 1996, p. 93.

J. Maritain, Od filozofii człowieka do filozofii wychowania, Polish translation by A. Ziernicki, [in:] Człowiek, wychowanie, kultura. Wybór tekstów, edited by F. Adamski, Kraków 1993, p. 135. issue 2, p. 7.

M. Gogacz, Podstawy wychowania, Niepokalanów 1993, p. 9.

K. Wojtyła, Osoba: podmiot i wspólnota, "Rocznik Filozoficzny", 1976 vol. 24, 
own personal nature. Because of philosophical dialogue (Buber, Marcel, Levinas), it becomes increasingly clear that "the human being becomes a person only in relation to another human being as a person. The human discovers his subjectivity and personhood in a dialogical relationship. As a result of this he discovers not only himself but also the world of values on which he bases his whole axiological world and the quality of his life." ${ }^{10}$ It should be added that the dialogical situation is not restricted to a dialogue with a specific other person, but it also applies to dialogue with past generations, one's own conscience, or with God. “The human being develops when he grows in the spirit, when his soul comes to know itself and the truths that God has implanted deep within, when he enters into dialogue with himself and his Creator." 11

In these dialogues the human being discovers, through the wisdom and beauty that is revealed to him, that which he already suspected, the good that is in him and in the world, the attractive and given good, encourages and demands perfection. This imperative is probably best expressed by the words: "So be perfect, just as your heavenly Father is perfect" (Mt. 5:48).

Let us point out here that only a human being who believes in the sanctity of the world and of the life given to him has a lasting basis for finding his own dignity and pursuing perfection. It can be said that someone who has found his own dignity and lives up to his personal potential, who can direct his life as well as possible has reached full humanity and is human.

Someone who considers the world to be a mechanism, an organism, or chaos can be a good or evil person and his deeds can be good or evil. But it is of no importance, as his life in this world is of no importance because he has not found himself. Man does not find himself in all his uniqueness and irreducible specificity simply by recognizing that he is a part of a mechanism or body.

10 W. Pasierbek, Człowiek $w$ dialogu ze światem. Wprowadzenie, "Horyzonty Wychowania" 2002 no. 1, p. 5.

11 Benedict XVI, Caritas in veritate, Roma 2009, no. 76. 


\section{Practical axiology}

If we recognise the sanctity of the world and the sanctity of the life given to us, we must assume the human being to be of the highest value in the natural order and his relation with God to be the main source of his efforts to improve himself and the world.

Values show a human being the world of opportunities and motivate him to fulfill them. By following the good, revealed by these values, the human being becomes himself. "The human being lives through various values, but in his deeds he makes good real. It is the goodness of his own being, the objective personal perfection. It is also the good of the world of which the human is a part [...] And finally the good of God [...] By sheer acting, man reveals the perfection of the Creator. Christian ethics teach a man how he can and how he should attach the value of an objective good to his actions. The human being is aware of this good and directly experiences values. Man's whole moral life consists of experiencing values." 12

It must be added that the dynamic character of human nature and aspirations to become better reveal values that stimulate individual development. These are real, authentic values, but we also see false values, leading to stagnation, apathy, despair and a feeling of powerlessness. Following authentic values enables a human being to discover his own dignity, his own value, and, in consequence, to integrate his pursuits and focus on what is of real importance in his life.

We recognize values gradually, through desires, longings, experiences, and events that force us to make a choice. Choices reveal the values we prefer and those we respond to. In accordance with these values, we make judgments, intuitive at first and then more and more conscious. We perceive ourselves, and the world, through the perspective of our values and they allow us to comprehend $\mathrm{it}^{13}$. One cannot live without value judgments; modern theories establishing reason as the

12 K. Wojtyła, Elementarz etyczny, Lublin 1983, pp. 72-73.

13 Cf. R. Ingarden, Wykłady $z$ etyki, Warszawa 1989, pp. 348-349. 
supreme value, as a measure of every act of thinking or non-thinking, action or inaction, make such judgments as well, according to their own understanding of normality. However, reason that lacks reference to the human being misguides us very often. One of the mistaken paths is the attempt to eradicate some values from social life.

The diversity of values remains necessary for action and self-fulfilment as a subject, at the same time serving as a means of communication for varying consciousness, leading to their unification or separation. However, contemporary attempts to reduce the world to lower values is the main cause of the disintegration of spiritual unity of the persons participating in this communication and by restricting this communication make it impossible for its participants to understand themselves.

One can easily notice that freedom provides the basis for finding one's place in the world of values. As Tadeusz Gadacz concisely put it, "freedom always gives us reference to the world of values." ${ }^{14}$ Regardless of one's views, freedom remains one of the most important demands of people participating in social life.

Thanks to freedom, we discover the world of values, but also the world of values discovers our freedom for us. We see that we cannot avoid freedom, although today there are attempts to provide us with only a small range of actual possibilities under the guise of the freedom of choice, or even to suggest false values. People are told: you are free, you can choose between so many different kinds of cars, TV sets, shoes... Each of them has some specific "value", like durability, low price, or the prestige offered to its buyer. But in reality, the opportunities offered to us are small and are only intended to divert our attention from the real possibility of the freedom to pursue our own aspirations.

Therefore, to make use of freedom one also needs to understand it. It is impossible to grasp it in a speculative way, as it manifests itself only through the action in which it is fulfilled, in deeds, and participation

14 T. Gadacz, Wychowanie do wolności, [in:] Ewolucja tożsamości, edited by H. Kwiatkowska, Warszawa 1994, p. 102. 
undertaken by man. However, it remains a gift from God, challenging us to become what we are. As the French philosopher Louis Lavelle wrote, "the relationship between our freedom and the freedom of God contains the mystery of creation." ${ }^{15}$ Due to this reference to God, authentic and full freedom enables one to learn the difference between things that are valuable and those that are convenient. It allows for a distinction between created and genuine values found through creativity. This might be the source of an axiological intuition that allows us to recognise the very "height" of values ${ }^{16}$ and their importance to our existence. The ability to see their rise makes it possible to realise what is important to us and orders various values and their hierarchies.

Here, of course, we are referring to internal freedom, the freedom "to" - the one that gives us the feeling of integration and gives meaning to our actions. Freedom "to" is the freedom of the person who wants to express himself through his actions seeking its meaning. A person who continues to seek meaning is responsible not only for this meaning but also for the other man, trying to find this meaning together with him.

An internally free person, finding his "own" values and realizing himself through their implementation, becomes authentic and finds his own value. At the same time, someone who has a feeling of self worth feels responsible for his own development. He pursues an internal and external integration, compatibility of thoughts, words and actions - towards self-fulfilment. It must be also emphasised that only someone who has a sense of his own value can take an attitude of "openness" towards the world of other values and is able to find value in another human being. Such a person is ready to ask: how can you help me and how I can help you? This is an important step towards what Karol Wojtyła called "integration of love in a person and between persons." ${ }^{17}$ Only someone who has a sense of his own value, who has "reclaimed" his own dignity, has found the truth of his own existence, is ready to go "beyond himself," toward 
selfless love. What is more, as Benedict XVI emphasised, "[t]ruth, by enabling men and women to let go of their subjective opinions and impressions, allows them to move beyond cultural and historical limitations and to come together in the assessment of the value and substance of things. Truth opens and unites our minds in the logos of love: this is the Christian proclamation and testimony of charity. In the present social and cultural context, where there is a widespread tendency to relativize truth, practising charity in truth helps people to understand that adhering to the values of Christianity is not merely useful but essential for building a good society and for true integral human development." 18

Here we recognise the first important goal of Christian education. It must focus on the liberation of the human being from the stereotypes of social behaviour, stemming from the concept of external freedom. It must also give rise to dignity, showing the perspective of inner freedom and teach how to use it. Values, such as dignity and freedom, are not gifts they are tasks. They are to be discovered by both the teacher and the pupil. To call attention to dignity, to restore a sense of dignity, is the first step in finding personal being and that is why on this question John Paul II took a decisive, uncompromising attitude: "Because there can be no freedom apart from or in opposition to the truth, the categorical - unyielding and uncompromising - defence of the absolutely essential demands of man's personal dignity must be considered the way and the condition for the very existence of freedom." ${ }^{19}$ Only free and dignified people are capable of "[a] love which thus causes each of them to be loved for himself, so that through him, and for him, other men will open their souls to the love of humanity." 20

By finding his own freedom, dignity, and love, a human being is able to find communion with God and with other people. We must remember here that everyone is different, and everyone realizes this based on various hierarchies of personal value. One person can express himself or herself and find this communion through poetry, science, music, or

\footnotetext{
18 Benedict XVI, Caritas in veritate, no. 4.

19 John Paul II, Veritatis splendor, no. 96.

20 H. Bergson, The two sources of morality and religion, London 1935, p. 81.
} 
helping others - the diversity of values is given so that everyone can choose their own path to self-fulfilment. There are many Christian values; not only love, but also compassion, humility, and others that can prove useful on this way to self-fulfilment.

There are also many "worldly" values, which can bring about self-realisation. The previously mentioned global values such as: liberty, equality, fraternity, solidarity, environmental responsibility; local values: motherland, the place with which we can identify, friendship; and individual values: justice, truthfulness, wisdom, diligence, honesty, responsibility. All these values as long as they are implemented with God and the "universal values, centred around the transcendental triad of truth, goodness, and beauty" 21 in perspective, are Christian values and, what is more, they stem from the Christian tradition.

\section{Educational imperatives (applied axiology)}

Christian pedagogy faces a great challenge: unless it is to repeat its own and others' mistakes, contributing to worsening the axiological crisis, it needs to develop its own educational methods, based on the Christian vision of man and Christian values.

Tadeusz Gadacz took up the issue of his time when he asked what Christian education should be like. Gadacz proposed a being-centred education that "is creative and dynamic, open, and always tends towards what is better, truer and more beautiful. Its purpose is the love of God, which is the source of all creativity." 22 I fully agree with the author that the latter model is more suitable for not only Christian education, but education in general. Especially, in my opinion, the purpose of education should be to awaken man to his dignity and to further his sense of self-worth. If we forget about dignity, then we forget about the purposefulness of human existence. ${ }^{23}$

${ }^{21}$ K. Denek, Uniwersalne wartości edukacji szkolnej, “Dydaktyka Literatury” 1996 t. 16, p. 75.

22 T. Gadacz, Wychowanie jako spotkanie osób, “Znak” 1991 no. 436, p. 68.

23 Cf. K. Wojtyła, Osoba i czyn, Lublin 1994, p. 419. 
Also secular theorists see the need of changing the educational model, as evidenced by their appeal: "We want to teach how to adapt, how to operate in the world as it is, but also to warn against the dangers of conformity and to some degree encourage revolt. We want to nurture criticism and creative thinking, but also to shape the attitude of fidelity to reality or even 'the love of everything that exists."'

This appeal recalls the comparison, made by Zygmunt Bauman, of the old education model and the one postulated by, among others, Tadeusz Gadacz. In the previous model, a human being was treated like a ballistic missile. The educators thought that it is enough to set goals, measure the distance, determine the initial parameters and fire the pupil into the world. However, nowadays we can see all too clearly that this model fits neither the modern world nor man.

The human being is more like a cruise missile that must change its course during flight, must learn all the time, update and process data but also must have a designated purpose. For Christians, this goal is of course an encounter with God, but we have to find the right path to this goal in our earthly existence.

This is why we must educate for freedom and responsibility. The responsible approach is toward a life associated with freedom and creativity and open to values. Karol Wojtyła emphasised this aspect, adding: "Man can be liable for his actions and experiences responsibility because he has the power to respond to values with his will." ${ }^{25}$ Freedom and responsibility are shaped alongside the pupil's character. This character cannot be forged by force, but by showing him positive examples and the opportunities that the beautiful, wise, and good world opens for us.

The contemporary world is affected by a crisis of will, as Friedrich W. Foerster already recognized in the first half of the last century. "The desperate need for entertainment today, this passionate bustle, this feverish activity, are in fact nothing more than man's escape from himself 
and from a deeper knowledge of himself." ${ }^{26}$ People make easier, more superficial choices, ones that bring quicker results, without sufficent care. They sell their souls for trinkets. They do not see much point in their own existence and, having lost respect for themselves, they do not see the possibility of enjoying their own inner life. This does not mean that they cannot get back this inner life and spontaneous joy or satisfaction with their own actions. It is necessary to show the person both his potential greatness and his vanity, and to give him a choice. Young people quite often spontaneously choose striving for the better, and we need to support them in this. We need to "encourage" the hidden persons in them and help them to develop self-awareness as well as assist them in identifying their own strengths, weaknesses, and goals, show positive examples of best practices and strengthen their best traits of character.

Let us not ask our pupils to abandon the natural world - we cannot all be saints - but show them that, with the divine perspective in mind, they can gain a sense of their own worth and can change the world with their power. This is not about some sentimentality but about supporting strength of character - the kind that will resist false pretences in the modern world and will provide an example that one can be oneself.

It is beneficial to recall once again the pedagogical proposals of Friedrich W. Foerster. Moral perfection is just a way for him, not the ultimate goal. The desire to learn the truth about oneself always returns the knowing subject to the source, to the truth of God, the image of what a human being is in his essential, personal structure. ${ }^{27}$ It is important that man, who remains the greatest value in the natural world, does not lose sight of the highest good, which is God, because only with a perfect example in mind can he strive for perfection himself. "God gives what in us is higher, the light of conscience, a clear sense of purpose and unwavering stability. He alone saves us from all the pettiness, from terrors

26 F. W. Foerster, Światło wiekuiste a ziemskie ciemności. Nasza współczesność z punktu widzenia wieczności, Polish translation by Z. Starowiejska-Morstinowa, Katowice 1938, p. 55.

27 Cf. E. Smołka, Filozofia kształtowania charakteru. Fryderyka Wilhelma Foerstera teoria wychowania w świetle założeń personalizmu chrześcijańskiego, Tychy 2005, p. 40. 
and contradictions, typical of a being that only revolves around itself and tells us that our every action refers to something infinitely higher than what is human." ${ }^{28}$ God is the purpose present in every man, the hidden Good News that needs to be discovered.

Today's educational projects lack an ideal that would provide a point of reference for students and yet "[1]ife exists for a purpose, which makes it worthy of living," 29 and moving towards God by doing good is an ideal attractive to many. Foerster, as cited above, assumed that by choosing a direction compatible with the Good a human being can act in accordance with free will. Then his every step will be guided towards moral perfection. Foerster emphasized, however, that one of the "basic conditions for the formation of character is to know and to understand the values that constitute the educational ideal." 30

Here we come to another question, the question of competence. Our requirements towards pupils may be effective only when we deeply understand the values that constitute the educational ideal of Christianity. Only then will we be able to pass on this profoundly understood knowledge to others.

An educator is someone who helps the student discover the world of values while respecting his autonomy. Values must have an impact through their strength - but first they must be uncovered for the student, preferably through dialogue. One of the best teachers I have ever had, Józef Tischner, emphasised this: "Education is work with a person - one who is in the state of maturation. Education creates a bond between the teacher and the pupil analogous to the relationship of paternity [...] Through the work of the educator truth is born in a human soul. Truth becomes human strength. The educator does not create this truth $[. .$.$] He only helps, joining the man's efforts with his own." { }^{11}$

$28 \quad$ F. W. Foerster, Chrystus a życie ludzkie, Warszawa 1926, p. 144.

29 J. Maritain, Od filozofii..., p. 140.

30 W. Cichoń, Wartości..., p. 103.

31 J. Tischner, Wychowanie, [in:] idem, Etyka solidarności i homo sovieticus, Kraków 1981, p. 74. 
It is also important for the educator to be the one who bears witness, presents, and represents values. Even the most knowledgeable teacher is not able to pass on his knowledge if he has no authority; it is not about the authority of the institution, his authority as a teacher or even a professor, but personal authority, obtained as a result of the adequacy of the truth proclaimed by his own actions, which makes him credible. Such an exemplary educator, giving testimony of his own truth, experienced and understood, can reach everyone, even when talking to a great many people. John Paul II, Józef Tischner were, and Pope Francis is as well, capable of this art. Jesus Christ was also such a Teacher, uniting divine and human nature in one human person, the perfect model for us. Christ showed us the proper way of teaching. Of course, "Jesus Christ was not only a great model to follow as a person, but he was also an ethical lawmaker, preaching to the whole of humanity the will of God." ${ }^{32}$ His teachings and the call to love have been the moral imperative for our culture and for every human being for more than two millennia. In a world that is turning away from His message, we see with increasing clarity, that morality and natural law are not enough for us we need love as well.

As emphasized by John Paul II: "You cannot understand who a person is nor what is his proper dignity, his vocation, or ultimate destiny. You cannot understand any of that without Christ." ${ }^{33}$ Therefore, our teaching must still refer to His wisdom, goodness, and love to everything he has given us.

\section{Bibliografia}

Benedict XVI, Caritas in veritate, Roma 2009.

Bergson H., The Two Sources of Morality And Religion, London 1935.

Cichoń W., Wartości, człowiek, wychowanie. Zarys problematyki aksjologiczno-wychowawczej, Kraków 1996.

${ }^{32}$ K. Wojtyła, Ocena możliwości zbudowania etyki chrześcijańskiej przy założeniach systeтu Maxa Schelera, [in:] idem, Wykłady lubelskie, Lublin 2001, p. 52.

33 John Paul II, Musicie od siebie wymagać, Poznań 1984, p. 39. 
Denek K., Uniwersalne wartości edukacji szkolnej, “Dydaktyka Literatury” XVI 1996.

Foerster F. W., Chrystus a życie ludzkie, Warszawa 1926.

Foerster F. W., Światło wiekuiste a ziemskie ciemności. Nasza wspótczesność $z$ punktu widzenia wieczności, Polish translation by Z. Starowiejska-Morstinowa, Katowice 1938.

Gadacz T., Wychowanie do wolności, [in:] Ewolucja tożsamości, edited by H. Kwiatkowska, Warszawa 1994.

Gadacz T., Wychowanie jako spotkanie osób, “Znak” 1991 no. 436.

Gogacz M., Podstawy wychowania, Niepokalanów 1993.

Ingarden R., Wykłady z etyki, Warszawa 1989.

John Paul II, Veritatis splendor, Rome 1993.

Lavelle L., De l'Intimité spirituelle, Paris 1995.

Maritain J., Od filozofii człowieka do filozofii wychowania, Polish translation by A. Ziernicki, [in:] Człowiek, wychowanie, kultura. Wybór tekstów, edited by F. Adamski, Kraków 1993.

Pasierbek W., Człowiek w dialogu ze światem. Wprowadzenie, „Horyzonty Wychowania" 2002 no. 1.

Pickert E., Godność człowieka a życie ludzkie. Rozbrat dwóch fundamentalnych wartości jako wyraz narastajacej relatywizacji człowieka, Polish translation by J. Merecki, Warszawa 2007.

Radziwiłł A., O ethosie nauczyciela, "Znak” 1991 no. 436.

Smołka E., Filozofia kształtowania charakteru. Fryderyka Wilhelma Foerstera teoria wychowania $w$ świetle założeń personalizmu chrześcijańskiego, Tychy 2005.

Spaeman R., Osoby. O różnicy między czymś a kimś, Polish translation by J. Merecki, Warszawa 2001.

Wojtyła K., Elementarz etyczny, Lublin 1983.

Wojtyła K., Osoba: podmiot i wspólnota, "Rocznik Filozoficzny" 1976 vol. 24 issue 2.

Wojtyła K., Znak, któremu sprzeciwiać się będa, Poznań-Warszawa 1976. 